\title{
A DNA method for qualitative identification of plant raw materials in feedstuff
}

\author{
Stefano Tavoletti $\cdot$ Linda Iommarini $\cdot$ Marina Pasquini
}

Received: 12 January 2009 / Revised: 22 April 2009 / Accepted: 27 April 2009 / Published online: 13 May 2009

(C) The Author(s) 2009. This article is published with open access at Springerlink.com

\begin{abstract}
This research developed a simple and not expensive DNA method for the qualitative identification of plant raw materials used as feed mixtures. Specific simple sequence tagged (STS) markers were developed to detect faba bean (Lectin A gene), field pea (Convicilin A gene), grain sorghum (UDP-glucosyltransferase gene) and barley (Hordoindoline-a gene), whereas identification of durum and common wheat (lipid transfer protein gene), soybean (Gly $\mathrm{m} \mathrm{Bd} 30 \mathrm{~K}$ allergen gene) and maize (invertase gene) was carried out using markers available from the literature. Cross-reactivity of the primer pairs was also checked against oat, rye, kidney bean and lentil. The method was effectively applied to the analysis of flour mixtures and extruded feedstuff. It could be included in traceability and certification of animal feeding systems within high quality animal production chains which are strictly related to the production area by the valorisation of locally grown raw materials.
\end{abstract}

Keywords Traceability $\cdot$ Feed $\cdot$ Molecular markers . STS $\cdot$ PCR

\section{Introduction}

Consumer's interest toward high quality agricultural products has extended the meaning of product's quality to all steps of the production chain. This is true mainly for meat,

S. Tavoletti $(\bowtie) \cdot$ L. Iommarini $\cdot$ M. Pasquini

Dipartimento di Scienze Alimentari, Agro-Ingegneristiche, Fisiche, Economico-Agrarie e del Territorio (S.A.I.F.E.T.), Università Politecnica delle Marche, Via Brecce Bianche, 60131 Ancona, Italy

e-mail: s.tavoletti@univpm.it milk and dairy products, since the knowledge of the animal production system, and in particular of the animal feeding system, has been recognized as a further feature of final product quality. Moreover, feeding systems based on locally produced forages and feeds give to animal products a closer link to the area of origin, reflecting traditional systems of animal husbandry.

As a consequence, considerable attention has been given recently to increase the cultivation of grain legumes such as faba bean (Vicia faba L. subsp. minor) and field pea (Pisum sativum L.) that could replace soybean (Glycine max (L.) Merr.) meal as protein source. Moreover, barley (Hordeum vulgare L.), grain sorghum (Sorghum bicolor L. Moench) and other minor cereals could be revaluated as energy concentrates alternative to maize (Zea mays L.) grain. The increased use of these raw materials in animal feeding also stimulated farmers to reintroduce these crops in rational crop rotations particularly suitable for areas where irrigation is not practicable.

Several methods already applied to food traceability and authentication could be used to develop certification systems aimed at the qualitative and quantitative identification of the plant species used as raw materials for feedstuff production, as reviewed by Da-Wen [1] and Lees [2]. In particular, DNA markers have already been extensively applied for authentication and species identification in food of animal and plant origin and to detect genetically modified organisms (GMO) or contaminants in foods and flour for human consumption [3-8]. Moreover, advanced real-time PCR protocols have been recently developed to detect plant species within foods, such as pea in meat-based food [9] or gluten-containing cereals in gluten-free products $[10,11]$.

However, the valorisation of local animal production chains would benefit of specific, simple, efficient and not expensive feed certification systems. For this purpose DNA 
molecular markers can be applied to develop analytical methods that could guarantee consumers about the feeding system applied by the farmers. In the feed industry, PCR methods have been used mainly to assay feedstuff contamination with meat meal $[12,13]$, and less information is available about the application of DNA markers to analyze the composition of feed samples.

For this reason, a research has been carried out to develop a simple and not expensive DNA-based analytical method, which could be applied to certify animal feeding systems based on locally produced raw materials, focusing attention on field pea, faba bean, grain sorghum and barley which have been underutilized as feed components since the diffusion of commodities such as soybean and maize.

Therefore, the main objectives of the present research were:

1. identification of specific sequence tagged site (STS) markers for field pea, faba bean, grain sorghum and barley;

2. development of a qualitative PCR method for the identification of faba bean, field pea, grain sorghum and barley in feed mixtures including soybean, maize, durum wheat (Triticum turgidum L. ssp. durum (Desf.) Husn.) and common wheat (Triticum aestivum L. ssp. aestivum (Vill.) MK), the most diffused raw materials used by the feed industry;

3. test cross-reactivity of the primer pairs against species that are not usually included in feed mixtures: oat, rye, kidney bean and lentil.

\section{Materials and methods}

\section{Plant material}

Three legumes (faba bean, field pea and soybean) and five cereals (barley, durum wheat, common wheat, sorghum and maize), diffused as raw materials for feedstuff production, were used. To improve accuracy, a large sample of varieties was analyzed (Table 1). Few maize varieties were included because of the well-known species-specificity of maize DNA markers. Moreover, to increase information concerning primer pair specificity, also oat (Avena sativa $\mathrm{L}$., three varieties: Bionda, Donata, Fulvia), rye (Secale cereale L., one Italian population), kidney bean (Phaseolus vulgaris L., two varieties: Gipsy, Volturno) and lentil (Lens esculenta Moench, two varieties: Gaia, Itaca) were added in the present research.

Seeds were furnished by Centro Ricerche Produzioni Animali (CRPA), Reggio Emilia, Italy (faba bean, field pea, soybean), Centro Ricerche e Sperimentazione per il Miglioramento Vegetale "N. Strampelli", Tolentino, Italy (barley, durum wheat, common wheat, oat, rye, lentil and kidney bean), and Faculty of Agriculture, Università Politecnica delle Marche (sorghum and maize).

DNA samples from fresh tissues of young plantlets were used to test species specificity of primer pairs. Subsequently, a flour sample was obtained for each species by mixing and milling an equal amount of seeds of each available variety.

Moreover, a sample of an extruded feed, containing faba bean, field pea and soybean, was included in the study to test the effectiveness of the method on a sample produced by a technological treatment that could damage DNA integrity.

Development of specific sequence tagged site (STS) markers

Primer pairs for STS specific markers were designed from faba bean Lectin A (lecA), field pea Convicilin A ( $c v c A)$, sorghum UDP-glucose glucosyltransferase (UGT) and barley Hordoindoline-a (Hin-a) genes (software PRIMER3: http://frodo.wi.mit.edu/cgi-bin/primer3/primer3_www.cgi). STS markers already available from the literature were chosen to detect soybean (Gly m Bd $30 \mathrm{~K}$ allergen gene) and maize (Invertase gene, ivrl) [14, 15], and a primer pair amplifying the Lipid transfer protein (Ltp) gene was used to detect both durum and common wheat DNA [5, 16]. Oligonucleotides were purchased from SIGMA ALDRICH Co. (St. Louis, MO, USA).

Test of primer pairs

DNA samples were extracted from fresh and healthy leaves of six plantlets for each variety. Tissues were collected, bulked, frozen with liquid nitrogen and grinded. DNA extraction [17] was carried out using a CTAB buffer (2\% CTAB, $1.4 \mathrm{M} \mathrm{NaCl}, 20 \mathrm{mM}$ EDTA, $100 \mathrm{mM}$ Tris-base $\mathrm{pH}$ $8,1 \%$ B-mercaptoethanol) followed by phenol-chloroform (1:1) purification and $100 \%$ isopropanol alcohol precipitation. Pellets were washed with ethanol $(70 \%)$ and resuspended in TE (10 mM Tris-HCl, pH 8.0; 1 mM EDTA, pH 8.0). After RNAse treatment, DNA was precipitated with ethanol (100\%) and resuspended in TE.

DNA concentration was quantified by fluorimetry (DynaQuantTM 200, Hoefer Pharmacia Biotech Inc., San Francisco, CA, USA). PCR amplifications were carried out (GeneAMP PCR System 9700, Applied Biosystems) in a volume of $25 \mu \mathrm{l}$ containing a final concentration of $1 \times$ reaction buffer, $25 \mathrm{ng}$ of template DNA, $0.2 \mathrm{mM}$ of each dNTP, $2.5 \mathrm{mM} \mathrm{MgCl}{ }_{2}, 50 \mathrm{ng}$ of each primer, 0.8 Taq polymerase units (Euroclone Life Science Division, Italy) and nuclease free water. PCR reaction conditions were as follows: preheating $\left(3 \mathrm{~min}\right.$ at $\left.94{ }^{\circ} \mathrm{C}\right) ; 8$ touch-down cycles 
Table 1 List of the varieties used to test the species specificity of the STS markers

\begin{tabular}{|c|c|}
\hline Species $^{\mathrm{a}}$ & Varieties $^{\mathrm{b}}$ \\
\hline Faba bean (19) & $\begin{array}{l}1 \text { Albus, } 2 \text { Betty, } 3 \text { Castel, } 4 \text { Chiaro di Torre Lama, } 5 \text { Espresso, } 6 \text { Irena, } 7 \text { Lady, } 8 \text { Merkur, } 9 \text { Prothabat69, } \\
10 \text { Prothabon101, } 11 \text { Safir, } 12 \text { Scirocco, } 13 \text { Scuro di Torre Lama, } 14 \text { Sicania, } 15 \text { Vesuvio, } 16 \text { Vithabon, } \\
17 \text { Vulcain, } 18 \text { Polo, } 19 \text { Spada. }\end{array}$ \\
\hline Field pea (27) & $\begin{array}{l}20 \text { Alliance, } 21 \text { Amical, } 22 \text { Apache, } 23 \text { Athos, } 24 \text { Attika, } 25 \text { Cartouche, } 26 \text { Chambord, } 27 \text { Cherokee, } \\
28 \text { Cordial, } 29 \text { Starter, } 30 \text { Eden, } 31 \text { FDP960 15-21, } 32 \text { Galactic, } 33 \text { Hardy, } 34 \text { Iceberg, } 35 \text { Ideal, } \\
36 \text { Isard, } 37 \text { Javlò, } 38 \text { Jovial, } 39 \text { Pacific, } 40 \text { Pactol, } 41 \text { Pepone, } 42 \text { Prelude, } 43 \text { Royal, } 44 \text { Speleo, } \\
45 \text { Spirale, } 46 \text { Standal. }\end{array}$ \\
\hline Barley (24) & $\begin{array}{l}47 \text { Alce, } 48 \text { Aldebaran, } 49 \text { Aliseo, } 50 \text { Amillis, } 51 \text { Amorosa, } 52 \text { Cometa, } 53 \text { Caramel, } 54 \text { Estival, } 55 \text { Federal, } \\
56 \text { Kaleidos, } 57 \text { Ketos, } 58 \text { Marado, } 59 \text { Majorie, } 60 \text { Mattina, } 61 \text { Meseta, } 62 \text { Nikel, } 63 \text { Ninfa, } 64 \text { Nure, } \\
65 \text { Panthesis, } 66 \text { Ponente, } 67 \text { Rodorz, } 68 \text { Sixtine, } 69 \text { Sonora, } 70 \text { Vega. }\end{array}$ \\
\hline Durum wheat (30) & $\begin{array}{l}71 \text { Anco Marzio, } 72 \text { Asdrubal, } 73 \text { Casanova, } 74 \text { Catervo, } 75 \text { Chiara, } 76 \text { Ciccio, } 77 \text { Claudio, } 78 \text { Creso, } \\
79 \text { Dario, } 80 \text { Duilio, } 81 \text { Dylan, } 82 \text { Iride, } 83 \text { K26, } 84 \text { Neolatino, } 85 \text { Normanno, } 86 \text { Orfeo, } 87 \text { PR22D89, } \\
88 \text { Saragolla, } 89 \text { Sfinge, } 90 \text { Simeto, } 91 \text { Vendetta, } 92 \text { Achille, } 93 \text { Ariosto, } 94 \text { Caprì, } 95 \text { Colorado, } \\
96 \text { Levante, } 97 \text { Meridiano, } 98 \text { Orobel, } 99 \text { PR22D40, } 100 \text { Virgilio. }\end{array}$ \\
\hline Common wheat (25) & $\begin{array}{l}101 \text { Abate, } 102 \text { Albachiara, } 103 \text { Anapo, } 104 \text { Apache, } 105 \text { Aquilante, } 106 \text { Artico, } 107 \text { Aubusson, } \\
108 \text { Avorio, } 109 \text { Azzorre, } 110 \text { Bilancia, } 111 \text { Blasco, } 112 \text { Bokaro, } 113 \text { Bologna, } 114 \text { Botticelli, } \\
115 \text { Copernico, } 116 \text { Egizio, } 117 \text { Exotic, } 118 \text { Generale, } 119 \text { Isengrain, } 120 \text { Mieti, } 121 \text { PR22R58, } \\
122 \text { Profeta, } 123 \text { Sagittario, } 124 \text { Serpico, } 125 \text { Vittorio. }\end{array}$ \\
\hline Grain sorghum (26) & $\begin{array}{l}126 \text { Vivarais, } 127 \text { DK34, } 128 \text { Kalblanc, } 129 \text { Iside, } 130 \text { Kinggo, } 131 \text { Brise, } 132 \text { Queyras, } 133 \text { Brenus, } \\
134 \text { Taxus, } 135 \text { Classus, } 136 \text { Marcus, } 137 \text { Favorite, } 138 \text { Angelus, } 139 \text { Arsenio, } 140 \text { Aralba, } 141 \text { Ardito, } \\
142 \text { Armida, } 143 \text { PR88Y20, } 144 \text { Velox, } 145 \text { Talggo, } 146 \text { Reggal, } 147 \text { Jimggo, } 148 \text { Carggo, } 149 \text { Targga, } \\
150 \text { Laggon, } 151 \text { Puma. }\end{array}$ \\
\hline Soybean (24) & $\begin{array}{l}152 \text { Aires, } 153 \text { Ascanubi, } 154 \text { Atlantic, } 155 \text { Blanca, } 156 \text { Borneo, } 157 \text { Colorado, } 158 \text { Dekabig, } 159 \text { Demetra, } \\
160 \text { Fuku, } 161 \text { Goriziana, } 162 \text { Hilario, } 163 \text { Indian, } 164 \text { Nikir, } 165 \text { Nikko, } 166 \text { Pacific, } 167 \text { Pedro, } \\
168 \text { Pr91b92, } 169 \text { Pr91m10, } 170 \text { Pr92b63, } 171 \text { Regir, } 172 \text { Shama, } 173 \text { Sponsor, } 174 \text { Taira, } 175 \text { Zen. }\end{array}$ \\
\hline Maize (2) & 176 Tietar, 177 Famoso. \\
\hline
\end{tabular}

a Total number of varieties analyzed for each species is reported in brackets

${ }^{b}$ Each variety was coded by a progressive number

with a denaturation $\left(30 \mathrm{~s}\right.$ at $\left.94{ }^{\circ} \mathrm{C}\right)$, annealing (30 s) with decreasing temperature of $0.5^{\circ} \mathrm{C}$ per cycle, elongation $\left(45 \mathrm{~s}\right.$ at $\left.72{ }^{\circ} \mathrm{C}\right) ; 27$ cycles of denaturation $\left(30 \mathrm{~s}\right.$ at $\left.94{ }^{\circ} \mathrm{C}\right)$, annealing (30 s at temperature shown in Table 2$)$, elongation $\left(45 \mathrm{~s}\right.$ at $\left.72{ }^{\circ} \mathrm{C}\right)$; final extension $\left(5 \mathrm{~min}\right.$ at $\left.72{ }^{\circ} \mathrm{C}\right)$. A template-free negative control was included in each PCR run. PCR products $(10 \mu \mathrm{l})$ were analyzed by agarose gel $(1.5 \% \mathrm{w} / \mathrm{v})$ electrophoresis in $1 \times \mathrm{TBE}$ (100 mM Tris Base, $100 \mathrm{mM}$ Boric Acid, $2 \mathrm{mM}$ EDTA) buffer at 100-120 V for $1-2 \mathrm{~h}$.

Each DNA sample was subjected to PCR amplification using the universal 18S rRNA gene [3] to check DNA quality and all the primer pairs evaluated in this research. This approach allowed to test at the same time DNA quality, false positive and false negative results.

A qualitative scoring (presence/absence of the amplification product) was carried out to verify the species specificity of the primers and the absence of cross-amplifications. A primer pair was chosen to generate species-specific STS marker when all the varieties of this species gave the expected amplification product, while all the varieties of other species did not.

The experiment was planned following a hierarchical experimental design where among the species DNA amplification ability of each primer pair was evaluated using different varieties nested within each species [18]. The use of a large number of varieties increased the effectiveness of testing the ability of each primer pair to detect the among species variability. Moreover, it allowed the potential identification of within species sequence variation in the gene targeted by the STS marker, resulting in amplification products differing in size from expected ones or to the lack of amplification products. Each PCR was replicated twice using two independent DNA extractions from each variety to evaluate also the within variety repeatability of the PCR results.

To increase information concerning primer pair specificity, potential cross-reactivity was also tested against oat, rye, kidney bean and lentil, that are not usually included as raw materials in feedstuff. For these non-target species, DNA quality was tested by PCR using universal $18 \mathrm{~S}$ rRNA gene primers [3], together with an oat specific primer pair (Thionin gene, AveThio) and a primer pair (Late embryogenesis protein gene) amplifying both kidney bean and lentil DNA [5, 19]; moreover, the same primer pair already applied for common and durum wheat DNA amplification (Ltp gene) also amplified rye DNA, as previously reported [5]. 
Table 2 Features of STS markers used to identify plant raw materials included in the feed mixtures analyzed

\begin{tabular}{|c|c|c|c|c|c|}
\hline Taxon & Primer pairs & $b p^{a}$ & GenBank ID & Annealing $^{\mathrm{b}}$ & Reference \\
\hline Eukariota & $\begin{array}{l}\text { EUKF } \\
\text { 5'agcctgcggcttaatttgac } 3^{\prime} \\
\text { EUKR } \\
\text { 5'caactaagaacggccatgca } 3^{\prime}\end{array}$ & 120 & - & 57 & {$[3]$} \\
\hline $\begin{array}{l}\text { Phaseolus vulgaris L. } \\
\text { Lens esculenta Moench. }\end{array}$ & $\begin{array}{l}\text { DPH100L } \\
\text { 5'catgtgcagcgagtggtact 3' } \\
\text { DPH100R } \\
\text { 5'aagcaaatcccaaatccaaa 3' }\end{array}$ & 100 & AF240774 & 58 & {$[5]$} \\
\hline Avena sativa $\mathrm{L}$. & $\begin{array}{l}\text { AveThio1 } \\
5^{\prime} \text { cgagttctgcaacacgggat } 3^{\prime} \\
\text { AveThio2 } \\
5^{\prime} \text { ggctgcaactgatgcacg } 3^{\prime}\end{array}$ & 265 & AB072338 & 60 & {$[5]$} \\
\hline Vicia faba $\mathrm{L}$. & $\begin{array}{l}\text { FbLecA1-F } \\
5^{\prime} \text { caactggtgaaatcacttccttcag } 3^{\prime} \\
\text { FbLecA1-R } \\
5^{\prime} \text { gcagttttgtcataatctttgccatt } 3^{\prime}\end{array}$ & 343 & AJ438490 & $60-56$ & $*$ \\
\hline Pisum sativum $\mathrm{L}$. & $\begin{array}{l}\text { CvcA1-F } \\
5^{\prime} \text { gaggttgtgcaatttctttctctc } 3^{\prime} \\
\text { CvcA1-R } \\
5^{\prime} \text { tcgattattacgcaactcctcttac } 3^{\prime}\end{array}$ & 164 & X06398 & $60-56$ & $*$ \\
\hline Hordeum vulgare $\mathrm{L}$. & $\begin{array}{l}\text { Hina-F } \\
5^{\prime} \text { cctagggacaaagctagattcetg } 3^{\prime} \\
\text { Hina-R } \\
5^{\prime} \text { 'actcaactgactgcaacaatcgt } 3^{\prime}\end{array}$ & 145 & DQ269851 & $63-59$ & $*$ \\
\hline Sorghum bicolor L. Moench & $\begin{array}{l}\text { SbUGT1-F } \\
\text { 5'ctgcccagagaagtggagag } 3^{\prime} \\
\text { SbUGT1-R } \\
\text { 5'caccacgcgttcaacattac 3' }\end{array}$ & 165 & AF199453 & $63-59$ & $*$ \\
\hline $\begin{array}{l}\text { T. aestivum L. ssp. aestivum (Vill.) MK } \\
\text { T. turgidum L. ssp. durum (Desf.) Husn. } \\
\text { Secale cereale L. }\end{array}$ & $\begin{array}{l}\text { LTPBd1-F } \\
\text { 5'gcgctcaggtaatgctca } 3^{\prime} \\
\text { LTPBd2-R } \\
\text { 5'tcctcgttgagattgtggat } 3^{\prime}\end{array}$ & 262 & X63669 & $61-57$ & {$[5,16]$} \\
\hline Zea mays $\mathrm{L}$. & $\begin{array}{l}\text { Ivr7 } \\
5^{\prime} \text { cgctctgtacaagcgtgc } 3^{\prime} \\
\text { Ivr9 } \\
5^{\prime} \text { ccgtttcctagctcattgtcg } 3^{\prime}\end{array}$ & 248 & U16123 & $64-60$ & {$[15]$} \\
\hline Glycine $\max$ (L.) Merr. & $\begin{array}{l}\text { Gly30K-6F } \\
5^{\prime} \text { gccacgggagccatagaagc } 3^{\prime} \\
\text { Gly30K-6R } \\
5^{\prime} \text { tggctttgcatctaccetctt } 3^{\prime}\end{array}$ & 208 & AB013289 & $64-60$ & [14] \\
\hline
\end{tabular}

* Primer sequences developed in the present research

a Amplicon expected size (base pairs)

${ }^{\mathrm{b}}$ Higher and lower annealing temperature $\left({ }^{\circ} \mathrm{C}\right)$ of touchdown PCR

Flour mixture analysis

To carry out flour analysis, DNA was extracted from 20 to $50 \mathrm{mg}$ of each sample and amplified using Extract-N-Amp ${ }^{\mathrm{TM}}$
Seed PCR Kit (Sigma Aldrich Co.) following the manufacturer's protocol. PCR and gel electrophoresis were carried out as already described for testing primer specificity. This protocol was also applied to analyze the sample of extruded feed. 
To check possible cross-contaminations, three sub-samples of each flour were tested by PCR using all the speciesspecific primer pairs previously identified. For each species, when DNA of at least one sub-sample amplified the STS marker of non-target species, the whole flour sample was considered contaminated, and a new flour was prepared and PCR tested again for cross-contamination. Submitting each flour to these PCR tests also excluded the risk of subsequent detection of false negatives due to DNA degradation consequent to the milling process and/or the presence of PCR inhibitors. Therefore, eight uncontaminated flour samples, one for each species, were used to prepare eight series of flour mixtures, one for each species. Within each series, flour of the species under examination was included at different concentrations $(0,0.9,5,10$ and $100 \%$ ) and the remaining species were included at equal amounts. The durum wheat flour serial dilution was obtained without including common wheat and vice versa. DNA of each mixture was tested using all the STS species specific markers. Within each serial dilution, the seven STS markers were expected to be amplified in all the mixtures but the $0 \%$ where only the STS marker of the species not included should not be detected. Therefore, repeatability of each STS marker was simultaneously tested by 40 PCR reactions (5 flour dilutions $\times 8$ species), the Ltp gene STS marker being tested twice.

Concerning the $0 \%$ mix, possible false negative results were avoided by the effective DNA amplification of STS markers detecting the other species included in the mixture. Moreover, each PCR amplification was carried out in duplicate.

\section{Results and discussion}

STS marker development in field pea, faba bean, grain sorghum and barley

A faba-bean specific STS marker (Table 2) was identified within the coding region of the lecA gene [20; GenBank ID no. AJ438490] by comparing pea, faba bean and soybean lectin gene sequences. The primer pair (FbLecA1-F and FbLecA1-R) amplified a 343-bp amplicon, which was present only when DNA of faba bean varieties was used as template for PCR reactions (Fig. 1a-c).

Nucleotide sequence of pea $c v c A$ gene, including its $5^{\prime}$ and $3^{\prime}$ flanking regions [21, GenBank ID no. X06398] was compared to soybean conglycinin, pea vicilin and faba bean vicilin genes. A primer pair (cvcA1-F and cvcA1-R) generating a 164-bp PCR amplicon was identified in the $3^{\prime}$ flanking region (Table 2). DNA gel electrophoresis confirmed that the expected band was amplified only by genomic DNA extracted from the 27 field pea varieties, whereas none of the varieties belonging to the other species included gave positive PCR amplification (Fig. 1d-f). Therefore, this STS marker proved to be an excellent marker for the identification of pea DNA in DNA mixtures.

A S. bicolor STS marker was developed from the mRNA sequence (GenBankTM no. AF199453) of the UDPglucose: $p$-hydroxymandelonitrile- $O$-glucosyltransferase (UGT) gene [22] that catalyzes the last step of dhurrin synthesis. A sequence homology ranging between 63 and $88 \%$ was found between Sorghum and the UGT gene sequences

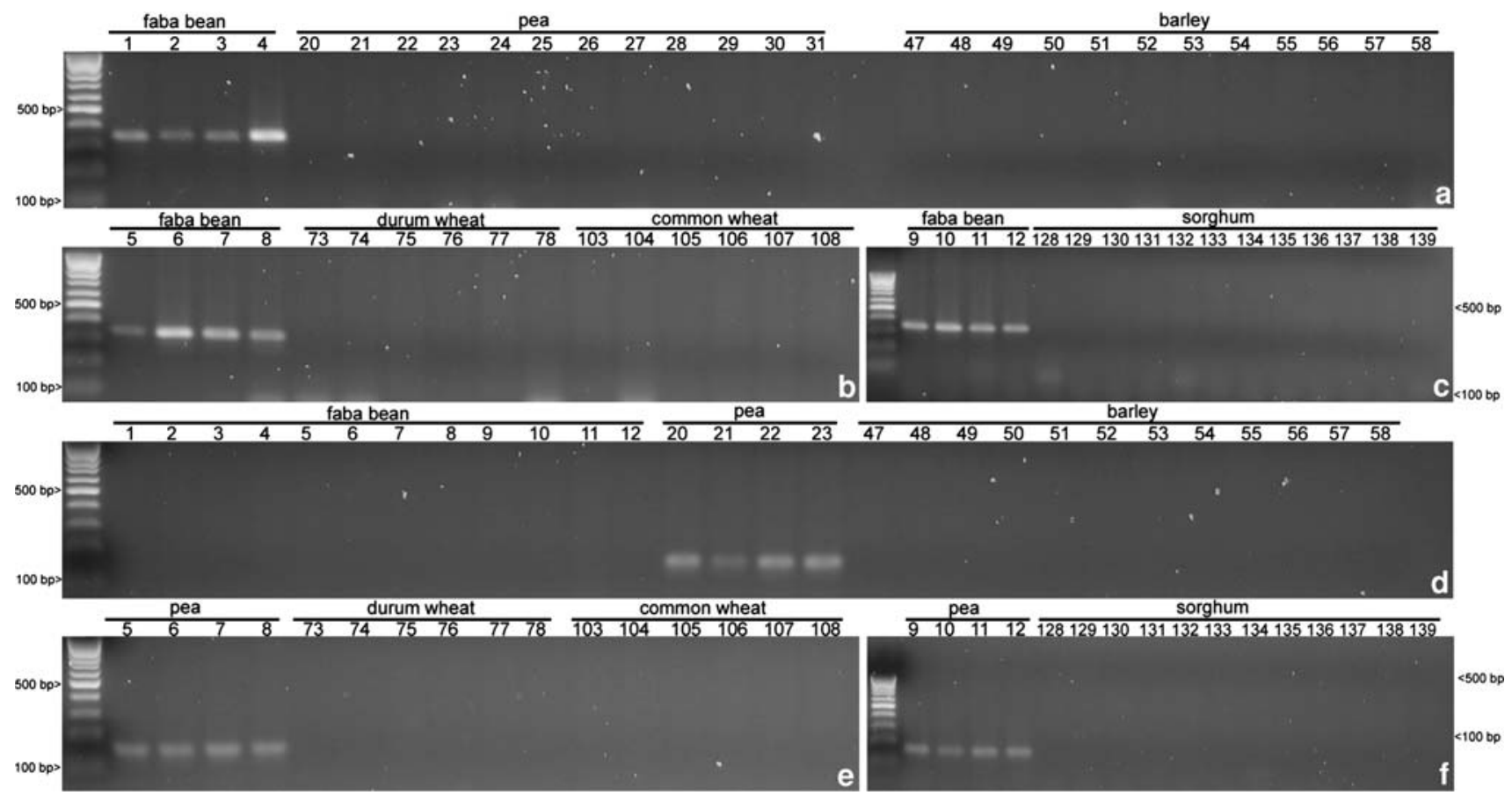

Fig. 1 Test of STS marker species specificity in faba bean $(\mathbf{a}-\mathbf{c})$ and field pea $(\mathbf{d}-\mathbf{f})$. Lane numbers refer to the variety codes reported in Table 1 
available for barley, Oryza sativa L. (including both indica and japonica groups), common wheat and maize. The primer pair SbUGT1-F and SbUGT1-R (Table 2) was designed in the $3^{\prime}$ end of the gene sequence and amplified a 165-bp product specific for Sorghum DNA.

The Hordoindoline-a gene has been already used for barley DNA identification to detect contamination of chestnut (Castanea sativa Miller) flour [5]. Since the primer pair used by these authors amplified also wheat Puroindoline-a gene [5], for our purposes the Hin-a gene sequence [23; GenBank ID no. DQ269851] was analyzed to find a set of barley-specific primers. The Hina- $\mathrm{F}$ and Hina- $\mathrm{R}$ primers (Table 2) were chosen within regions of low sequence homology with the wheat Puro- $a$ gene and amplified a barley-specific $145 \mathrm{bp}$ fragment. The results obtained with the Hin- $a$ marker were confirmed by the use of the hordein gene marker [24] (data not shown).

STS markers of soybean, maize, durum and common wheat

Detection of soybean DNA was carried out using the set of primers Gly30K-6F and Gly30K-6R developed for the specific amplification of a 208-bp product from the nucleotide sequence of the soybean allergen Gly m Bd 30K DNA. This marker was chosen since its specificity was previously evaluated including DNA of faba bean, pea and other legumes as negative controls [14]. Our test for primer pair specificity confirmed that this marker amplified a fragment of the expected size only when DNA of the 24 soybean varieties was used, whereas genomic DNA of the remaining legumes and cereals included in the present research never showed PCR amplification products.

The importance of maize as a commodity and the need for accurate and repeatable methods for genetically modified maize quantification has triggered the development of PCR systems for maize specific DNA quantification. Particular interest for the aim of the present research was addressed to the use of maize primer pairs already available and whose specificity was previously tested against a wide range of species of different families including almost all the species involved in the present research. In the present research the primer pair ivr7 and ivr9 [15] was used for the qualitative PCR amplification of a 248-bp maize sequence of the invertase gene (ivrl). As expected, this primer pair detected the PCR amplification product of desired size from maize without cross-reaction with any of the other species including field pea, which was not previously evaluated.

Amplification of durum and common wheat DNA was realized by the Ltp gene primer pair already used for chestnut flour analysis that also amplifies rye DNA [5]. This cross-reactivity with rye did not influence the applicability of our method, since durum and common wheat are usually included in feed mixtures as wheat by-products of pasta or bread industry, whereas rye is not generally utilized for animal feeding. For the purposes of the present research, this primer set simplified the identification of wheat DNA, since a single PCR detected the expected $262 \mathrm{bp}$ amplicon in all durum and common wheat varieties and since rye was not used in flour mixture analysis. However, wheat- and ryespecific STS markers could be used if discrimination between these two species would be requested [24].

Cross-reactivity of STS markers with lentil, kidney bean, oat and rye

Figure 2 shows that high quality of DNA was extracted from the lentil, kidney bean, oat and rye varieties, as tested by the $18 \mathrm{~S}$ rRNA gene (Fig. 2a). Species specificities of lentil and kidney bean, oat and rye DNA markers are shown in Fig. $2 b-d$. In the test for rye marker specificity, a wheat DNA sample (mix of durum and common wheat) was included in the lane assigned to the positive control, since the Ltp gene marker is also amplified by both durum and common wheat, whereas for lentil, kidney bean and oat positive controls were not used. Interestingly, the late embryogenesis protein marker amplification products of lentil and kidney bean showed different sizes, lentil amplicon being slightly shorter than the kidney bean one (Fig. 2b). This could help to distinguish these two species using a single STS marker.

Figure 2e-1 shows that all the primer pairs developed in the present research to identify faba bean, field pea, sorghum and barley, and also primer pairs chosen to detect soybean and maize did not amplify rye, oat, lentil and kidney bean DNA. In these tests, one DNA sample of the species specifically detected by each primer pair was included as positive amplification control.

\section{Flour mixture analysis}

Within each flour serial dilution, the $0 \%$ mixture always amplified the DNA of all the species but the one which was not present in the mixture. Moreover, each species was always detected even though it was added at a low amount $(0.9,5$ and $10 \%)$ as component of the flour mix, and analysis of the $100 \%$ component of each dilution series (pure DNA of each species) showed only the STS marker of the species under examination.

Figure 3 summarizes the results obtained for faba bean (Fig. 3a, b) and field pea (Fig. 3c-e). The faba bean $0 \%$ dilution did not show the faba bean STS marker (Fig. 3a), but it amplified the pea-specific STS marker (Fig. 3d). The same behavior characterized the $0 \%$ mix of the field pea flour dilution series, as shown in Fig. 3b, c. Moreover, faba bean (Fig. 3a, b) and field pea (Fig. 3c-e) STS-specific markers were always detected in all the flour mixtures 
Fig. 2 Cross-reactivity test of STS markers with lentil, kidney bean, oat and rye. *Variety names Rye1: Italian population; Oat1: Bionda; Oat2: Donata; Oat3: Fulvia; Lentill: Gaia; Lentil2: Itaca; Kidney Bean1: Gipsy; Kidney Bean2: Volturno

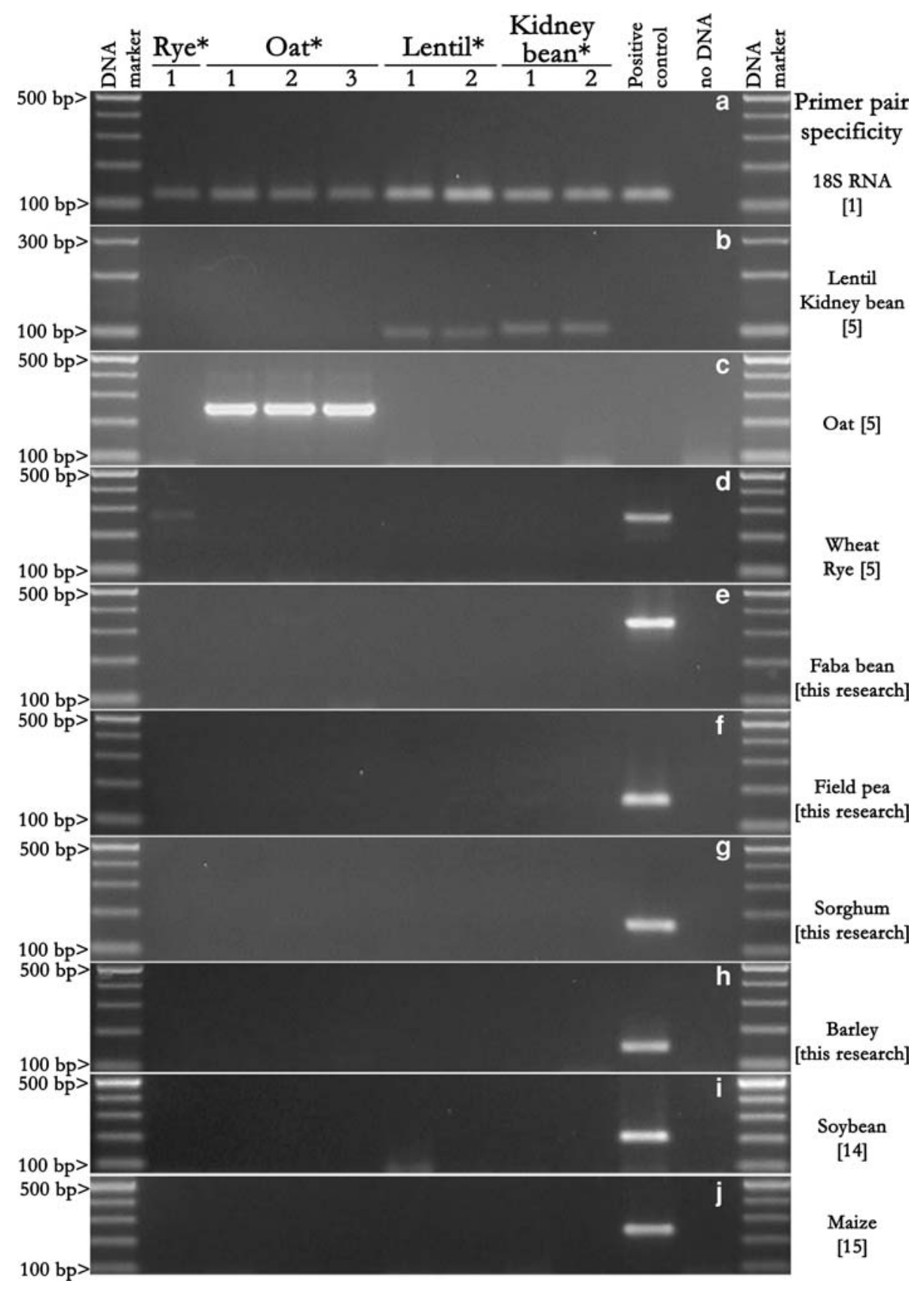

mixtures behaved as DNA extracted from young leaves tissue, confirming the effectiveness of the primer sets chosen for the qualitative evaluation of flour mixtures. Therefore, results of the qualitative PCR analyses of flour mixtures confirmed that the set of STS markers can be effectively applied to identify the species included as components of a feed.

Analysis of extruded feed sample

The applicability of the method to feedstuff produced by technological treatments that could damage DNA integrity was tested using a sample of an extruded mix of soybean

which is presently used to define a technically unavoidab feedstuff contamination [25]. DNA extracted from flour 


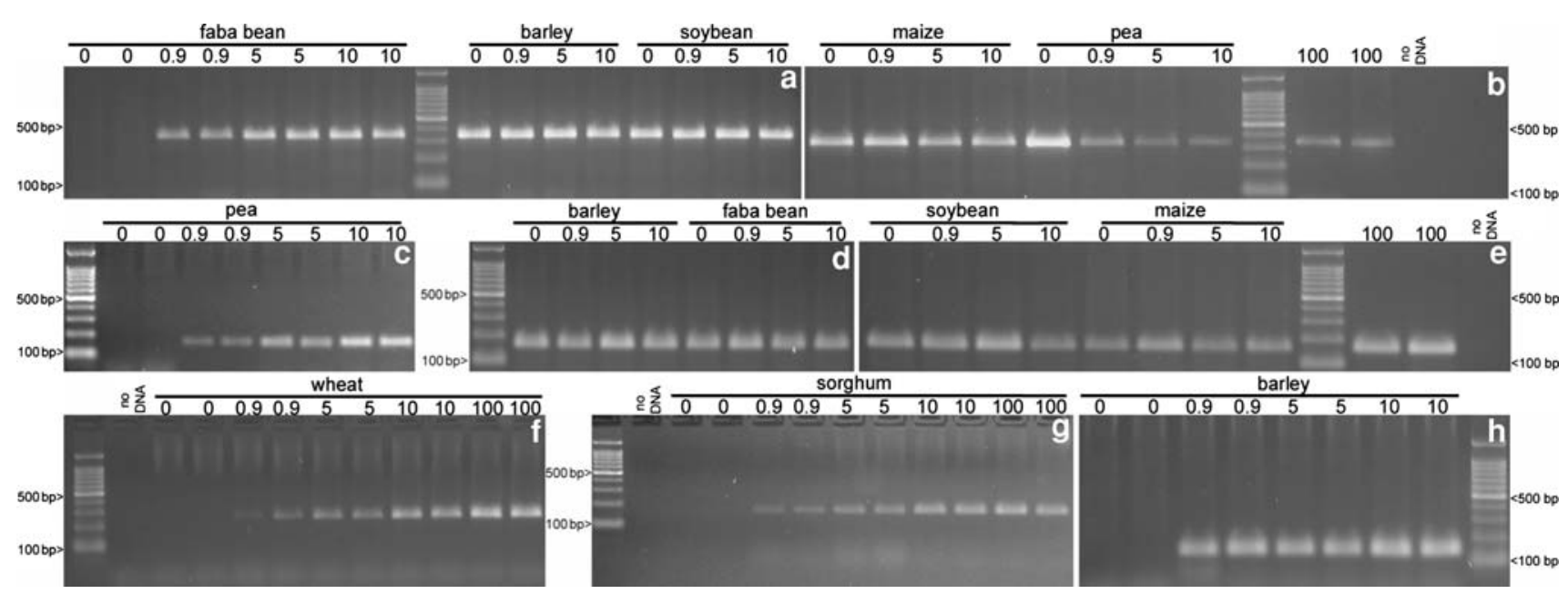

Fig. 3 Analysis of flour dilution series carried out with faba bean $(\mathbf{a}, \mathbf{b})$, field pea (c-e), wheat (f), grain sorghum (g) and barley (h) STS markers. Lane numbers shown under the species names refer to the relative percentage of the species under examination in the flour mix. Positive and negative controls are coded as "100" and "no DNA" lanes

extruded and the untreated flour mix containing maize. As a consequence, traces of maize could be easily detected also within the extruded mix, as evidenced by the results of the DNA analysis that confirmed also the high sensitivity of the method.

\section{Repeatability}

During the test of primer specificity few false-positives were identified: one for the $c v c A$ pea marker, two for the $U G T$ sorghum marker, two for the Hin- $a$ barley marker and two for the Ltp wheat/rye marker. Therefore, false positives appeared at low frequency and their presence was always detected for one out of the two independent DNA samples analyzed for each variety, suggesting they were due to DNA contamination instead of lack of primer pair species specificity. However, when false-positive samples were detected, two independent DNA samples of the variety
Fig. 4 Detection of STS species specific markers in the extruded feed sample was carried out in duplicate (a), together with a positive (left lane) and negative (right lane) control (b)

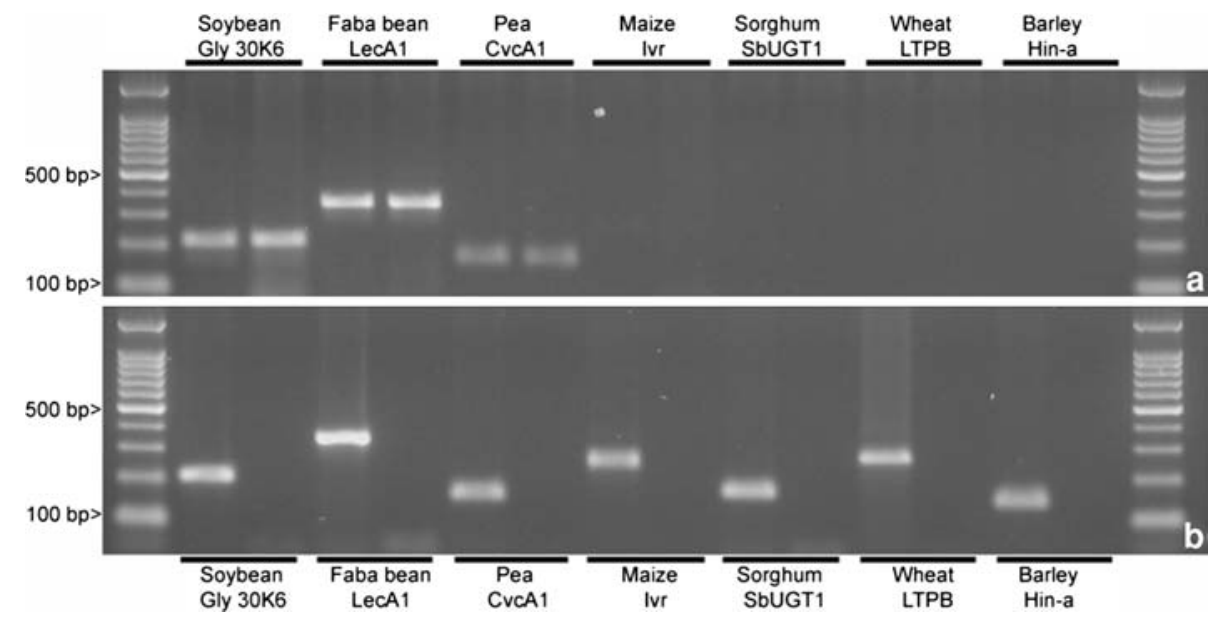


under examination were extracted again and subsequent PCR amplification always confirmed that they were due to accidental DNA contamination. False-negative results, that is the absence of one amplification product when it was expected to be present, were never detected. The analysis concerning flour mixtures and the extruded feed sample did not detect false positive or negative results.

Therefore, our approach suggests that two replicates of each DNA extraction could be sufficient to test both primer pair species-specificity and effectiveness of the PCR amplification conditions. The use of the present method for feedstuff analysis should therefore foresee at least two independent samples of DNA for each feed mixture tested.

\section{Conclusions}

Use of protein and energy concentrates as flour mixture is widely diffused in animal feeding systems, since it is cheaper than use of technologically treated feedstuff. Moreover, it represents a simple way, easily affordable by the farmers, to prepare on farm the feed mixture using raw materials and by-products of the farm itself. In Central Italy, and in particular in the Marche region, this traditional feeding system is still widely diffused in small farms of the inner part of the region where agriculture is strongly influenced by the environmental conditions, especially by the lack of irrigation during late spring and summer. These farms constitute a network of producers characterized by a high quality animal production chain often based on a "on farm" commercialization of the final products.

Recently, consumers have increased their attention toward local animal products obtained by production chains strictly related with the territory of origin. This aspect opened a new market for those farms interested in the economic valorisation of their products by exploiting the "from producer to consumer" commercialization system. However, an objective and not expensive method of feed certification aimed at showing which raw materials are used by single farms as ingredients for their animal feeding system is not available. On the other hand, the valorisation of these local production chains could benefit of a DNA method that could be applied within wider traceability systems. In fact, the main link of animal products to the area of production should be focused on the raw materials chosen as feedstuff and forage, since most, if not all, of the feed components should be legumes and cereals cultivated in the area where the farms are located.

The results of the present research show that a simple method based on qualitative DNA analysis carried out by PCR could represent a rapid and cheap strategy to certify local animal production chains. The effectiveness of this approach is confirmed by the large number of different varieties tested to evaluate STS markers' species specificity.

Application of this method will help focusing the attention of consumers on all the steps of local animal production chains by a precise, controlled and certified analytical system. Therefore, this PCR approach could represent the first step for a large-scale certification program, which could be applied at regional level to create a network of farms that could be identified and distinguished based on their animal feeding system. As a consequence, this increased request of local-certified products could also stimulate the reintroduction of the cultivation of grain legumes and cereals for animal feeding which have been almost completely neglected due to the prevalent use of commodities such as maize and soybean. Based on the results of the present research, the DNA approach will be extended to other forage and grain crops, to widen the range of possible combination of raw materials that could characterize a local animal feeding system.

Acknowledgments Research funded by the Marche Region, Project no. 13, title "Sviluppo di Filiere agro-zootecniche OGM free, sia convenzionali che biologiche, nella regione Marche" (Development of OGM free animal production chains, in conventional and organic agriculture, in the Marche region), L.R. 37/1999. Special thanks are also due to the Cooperativa "Stalla San Fortunato", Serra de' Conti (AN) for furnishing the extruded samples analyzed in the present research.

Open Access This article is distributed under the terms of the Creative Commons Attribution Noncommercial License which permits any noncommercial use, distribution, and reproduction in any medium, provided the original author(s) and source are credited.

\section{References}

1. Da-Wen S (2008) Modern techniques for food authentication. Elsevier, Amsterdam

2. Lees M (2003) Food authenticity and traceability. Woodhead Publishing Limited, Abington

3. López-Andreo M, Lugo L, Garrido-Pertierra A, Prieto MI, Puyet A (2005) Anal Biochem 339:73-82

4. Terzi V, Morcia C, Gorrini A, Stanca AM, Shewry PR, Faccioli P (2005) J Cereal Sci 41(3):213-220

5. Alary R, Buissonade C, Joudrier P, Gautier MF (2007) Eur Food Res Technol 225:427-434

6. Eugster A, Ruf J, Rentsch J, Hubner P, Koppel R (2008) Eur Food Res Technol 227:17-20

7. Gryson N, Messens K, Dewettinck K (2008) Eur Food Res Technol 227:345-351

8. Mafra I, Ferreira I, Oliveira M (2008) Eur Food Res Technol 227:649-665

9. Brežná B, Hudecová L, Kuchta T (2006) Eur Food Res Technol 222:600-603

10. Zeltner D, Glomb MA, Maede D (2009) Eur Food Res Technol 228:321-330

11. Piknová L, Brežná B, Kuchta T (2008) Eur Food Res Technol 47:114-119

12. Bellagamba F, Moretti VM, Comincino S, Valfrè F (2001) J Agric Food Chem 49:3775-3781 
13. Martín I, García T, Fajardo V, López-Calleja I, Rojas M, Pavón MA, Hernández PE, Gonzàles I, Martín R (2007) J Anim Sci $85: 452-458$

14. Torp AM, Olesen A, Sten E, Stahl Skov P, Bindslev-Jensen U, Poulsen LK, Bindslev-Jensen C, Andersen SB (2006) Food Cont $17: 30-36$

15. Hernández M, Duplan MN, Berthier G, Vaïtilingom M, Hauser W, Freyer R, Pla M, Bertheau Y (2004) J Agric Food Chem 52:46324637

16. Dieryck W, Gautier MF, Lullien V, Joudrier P (1992) Plant Mol Biol 19:707-709

17. Dellaporta SL, Wood J, Hicks JB (1983) Plant Mol Biol Rep 1:19_ 21

18. Sokal RR, Rohlf FJ (1981) Biometry. WH Freeman and Company, New York
19. Krahulcova J, Pangallo D, Piknova L, Siekel P (2003) Eur Food Res Technol 217:80-82

20. Lioi L, Galasso I, Santantonio M, Lenave C, Bollini R, Sparvoli F (2006) Gen Res Crop Evol 53:1615-1623

21. Bown D, Ellis THN, Gatehouse JA (1988) Biochem J 251:717726

22. Jones PR, Møller BL, Høj PB (1999) J Biol Chem 274:3548335491

23. Massa AN, Morris CF (2006) J Mol Evol 63:526-536

24. Sandberg M, Lundberg L, Ferm M, Malmheden Yman I (2003) Eur Food Res Technol 217:344-349

25. Regulation (EC) No 1829/2003 of the European Parliament and of the Council of 22 September 2003 on genetically modified food and feed. Off J Eur Union L 268:1-23 